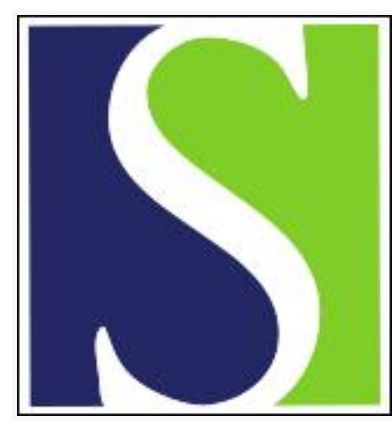

Scand J Work Environ Health 1990;16(3):158-162

https://doi.org/10.5271/sjweh.1798

Issue date: 01 Jun 1990

Postlabeling and immunoassay analysis of polycyclic aromatic hydrocarbons--adducts of deoxyribonucleic acid in white blood cells of foundry workers.

by Hemminki K, Randerath K, Reddy MV, Putman KL, Santella RM, Perera FP, Young TL, Phillips DH, Hewer A, Savela K

Affiliation: Institute of Occupational Health, Helsinki, Finland.

This article in PubMed: www.ncbi.nlm.nih.gov/pubmed/2382118 


\title{
Postlabeling and immunoassay analysis of polycyclic aromatic hydrocarbons - adducts of deoxyribonucleic acid in white blood cells of foundry workers
}

\author{
by Kari Hemminki, MD, ${ }^{1}$ Kurt Randerath, $\mathrm{MD},{ }^{2} \mathrm{MV}$ Reddy, $\mathrm{PhD},{ }^{2}$ Kim L Putman, MS, ${ }^{2}$ \\ Regina M Santella, PhD, ${ }^{3}$ Frederika P Perera, DrPH, ${ }^{3}$ Tie-Lau Young, MS, ${ }^{3}$ \\ David H Phillips, PhD, ${ }^{4}$ Alan Hewer, ${ }^{4}$ Kirsti Savela, $\mathrm{PhL}^{1}$
}

\begin{abstract}
HEMMINKI K, RANDERATH K, REDDY MV, PUTMAN KL, SANTELLA RM, PERERA FP, YOUNG T-L, PHILLIPS DH, HEWER A, SAVELA K. Postlabeling and immunoassay analysis of polycyclic aromatic hydrocarbons - adducts of deoxyribonucleic acid in white blood cells of foundry workers. Scand J Work Environ Health 1990;16:158-62. Blood samples were obtained from volunteers who were occupationally exposed to polycyclic aromatic hydrocarbons in a Finnish iron foundry and from referents not known to be occupationally exposed to this class of chemical carcinogens. Aromatic adducts were determined in the deoxyribonucleic acid of white blood cells from the exposed workers with the ${ }^{32} \mathrm{P}$-postlabeling and immunologic techniques. There was a correlation between the estimated exposure in a particular job and the adduct levels. Jobs of men with high adduct levels ( $>1$ adduct $/ 10^{7}$ nucleotides in the postlabeling assay) included sand preparation, molding, shake-out, and transport. The adduct levels were low in men in pattern making, melting, and fettling. This study suggests that ${ }^{32} \mathrm{P}$-postlabeling and immunoassay may be useful in monitoring human exposure to known and previously unidentified environmental genotoxic agents.
\end{abstract}

Key terms: ${ }^{32} \mathrm{P}-$ postlabeling, benzo[a]pyrene, DNA binding, occupational exposure.

The binding of chemicals to deoxyribonucleic acid (DNA) is thought to be the critical initiating event in tumor formation (1). Determining DNA adducts of carcinogenic agents has emerged as a possible method with which to monitor the exposure of humans (2-6). The procedures available include the ${ }^{32} \mathrm{P}$-postlabeling method (7-10), immunoassay (11-14), and scanning fluorescence spectroscopy (15-17). Qualitatively, the methods have been validated in a comparison between exposed populations and unexposed referents. The studied exposures of humans include tobacco smoke (18-20), polycyclic aromatic hydrocarbons (PAH) in the occupational environment $(15,21-27)$, and cisplatin in cancer chemotherapy $(11,13)$. To demonstrate the applicability of the methods in dose monitoring, dose-response studies should be carried out. We have previously participated in such a study on foundry workers using benzo[a]pyrene-DNA antibodies (24) and, to a limited extent, using ${ }^{32} \mathrm{P}$-postlabeling $(22,25,26)$. In this communication we report

\footnotetext{
1 Institute of Occupational Health, Helsinki, Finland.

2 Department of Pharmacology, Baylor College of Medicine, Houston, Texas, United States.

${ }^{3}$ Division of Environmental Sciences, School of Public Health, Columbia University, New York, New York, United States.

${ }_{4}$ Chester Beatty Laboratories, Institute of Cancer Research, London, United Kingdom.
}

Reprint requests to: Professor K Hemminki, Institute of Occupational Health, Topeliuksenkatu 41 a A, SF-02500 Helsinki, Finland. updated results by job categories of this large coded study using the ${ }^{32} \mathrm{P}$-postlabeling technique and immunoassay.

\section{Materials and methods}

Blood samples were obtained from healthy volunteers of a Finnish iron foundry in the course of two years. Information on job titles and smoking status was also collected.

Reference samples were obtained from individuals coming from different parts of Finland to the Institute of Occupational Health for examination. Their job titles did not indicate occupational exposure to PAH. Information on current smoking (cigarettes/ day) was obtained for all the subjects. The part of the study described in figure 1 and the part concerning some individuals in figure 3 have been previously described according to the estimated exposure levels $(22,24,25)$. The individuals added to the study (those represented in figure 2 and the rest of the individuals in figure 3 ) are different and hence cannot be directly compared.

Blood $(20-50 \mathrm{ml})$ was withdrawn into heparinized tubes and transported on ice to Helsinki. Cells were collected by centrifugation, and red blood cells were lysed by the process of washing twice with $0.15 \mathrm{M}$ ammonium chloride, each time followed by centrifugation at $1000 \mathrm{~g}$ for $5 \mathrm{~min}$. DNA was isolated from nuclei by treatment with pancreatic ribonuclease (RNase) and 
proteinase $\mathrm{K}$ followed by extraction with phenol and chloroform:isoamyl alcohol (24:1), as described earlier (25).

For the postlabeling, coded DNA samples $(4 \mu \mathrm{g})$ were dissolved in $0.1 \mathrm{mM}$ ethylenediaminetetraacetic acid (EDTA) and digested with micrococcal nuclease (0.14 units, Sigma Chemical Company, St Louis, Missouri, United States) and spleen phosphodiesterase (0.6 milliunits, Boehringer Mannheim, Federal Republic of Germany) in $17 \mathrm{mM}$ sodium succinate, $8 \mathrm{mM}$ calcium chloride, $\mathrm{pH} 6.0$ (total volume $4.8 \mu \mathrm{l}$ ) at $37^{\circ} \mathrm{C}$ for $20 \mathrm{~h}(7,10)$. The DNA digests were then further treated with nuclease $\mathrm{P}_{1}(1.0 \mu \mathrm{l}, 1$ unit, Sigma), 0.24 $\mathrm{M}$ sodium acetate, $\mathrm{pH} 5.0(2.4 \mu \mathrm{l})$, and $0.3 \mathrm{mM}$ zinc chloride $(1.4 \mu \mathrm{l})$. After incubation at $37^{\circ} \mathrm{C}$ for $1 \mathrm{~h}$, $0.5 \mathrm{M}$ Tris-base (tris[hydroxymethyl]aminomethane, $1.9 \mu \mathrm{l})$ was added. The DNA digest was then ${ }^{32} \mathrm{P}$ labeled as has already been described $(7,10)$. Carrierfree $\left({ }^{32} \mathrm{P}\right)$ orthophosphate obtained from Amersham International (Amersham, Bucks, England) was used to synthesize gamma-labeled ${ }^{32} \mathrm{P}$-adenosine 5'-triphosphate, of which $3.0 \mu 1$ [ $150 \mu \mathrm{Ci}(5.55 \mathrm{MBq})]$ was used in the labeling experiments. In the phosphorylation reactions three units of $\mathrm{T} 4$ polynucleotide kinase (Amersham) was added to catalyze the reaction, and incubation was for $30 \mathrm{~min}$ at $37^{\circ} \mathrm{C}$. The reaction was terminated by the addition of potato apyrase (40 milliunits, Sigma). Resolution of the ${ }^{32} \mathrm{P}$-labeled adducts was carried out on laboratory-made or Maserey Nagel polyethyleneimine-cellulose thin-layer chromatographic (tlc) sheets with the use of the following solvent systems: $0.1 \mathrm{M}$ sodium phosphate, pH 6.8 (dimension 1), 3.2 M lithium formate, $7.6 \mathrm{M}$ urea, $\mathrm{pH} 4.0$ (dimension 3 ), $0.1 \mathrm{M}$ sodium phosphate, $7.0 \mathrm{M}$ urea, $\mathrm{pH} 6.4$ (dimension 4), and $1.7 \mathrm{M}$ sodium phosphate, pH 6.0 (dimension 5). Adduct spots were detected by autoradiography with intensifying screens and quantitated by Cerenkov counting of the excised areas of the chromatograms. The determinations were carried out in duplicate assays at least. Because the determinations were carried out during an extended period of two years, during which the quantitation of adduct levels has improved, the results are given as semiquantitative adduct scores for the early samples and as absolute adduct levels for the later samples.

Coded samples were assayed by competitive enzymelinked immunosorbent assay (ELISA), essentially as described previously $(12,24)$. The 96-microwell black plates (MicroFLUOR “B," Dynatech Laboratories, Alexandria, Virginia, United States) were coated with $0.5 \mathrm{ng}$ of DNA modified by benzo[a]pyrene diol epoxide I (BPDE-I-DNA) (5 adducts $/ 10^{3}$ nucleotides or $15 \mathrm{pmol} / \mu \mathrm{g}$ ). A previously characterized rabbit polyclonal antibody was used at a dilution of 1:800 000 . A standard curve was constructed by the mixing of $50 \mu 1$ of diluted antibody with BPDE-I-DNA modified in vitro in carrier unmodified calf thymus DNA such that $50 \mu \mathrm{l}$ contained $0.25-25 \mathrm{fmol}$ BPDE-I-deoxyguanosine adduct in $50 \mu \mathrm{g}$ of DNA. All the human samples were also assayed at $50 \mu \mathrm{g}$ DNA/well after sonication and denaturation by boiling for $3 \mathrm{~min}$ and cooling on ice. A conjugate of goat antirabbit immunoglobulin G-alkaline phosphatase (Sigma) was used at a dilution of 1:400. The substrate, 4-methylumbelliferyl phosphate $(100 \mu \mathrm{l}, 50 \mu \mathrm{g} / \mathrm{ml} 0.1 \mathrm{M}$ diethanolamine, $\mathrm{pH}$ 9.6), becomes fluorescent after phosphate removal. Fluorescence was read on a microfluor reader (Dynatech Laboratories). Samples with greater than $20 \%$ inhibition were considered positive. For analytical purposes, samples with assays showing less than $20 \%$ inhibition were classified as "undetectable," and each was assigned a value of 1.0 adduct $/ 10^{8}$ nucleotides $(0.03 \mathrm{fmol} / \mu \mathrm{g})$, an amount midway between the lowest positive concentration and zero. The results have been presented as the means of the single assays with triplicate wells, and they are presented in terms of PAH-DNA, since it has been established that measured antigenicity may result from multiple diol epoxide adducts.

The significance testing was carried out by means of the one-sided Student's t-test.

\section{Results}

The effect of occupational exposure to the levels of white blood cell DNA adducts was studied in samples drawn immediately after a four-week vacation and three months later (table 1). With coded samples from the same individuals both postlabeling and immunoassay detected a large increase in the level of adducts after resumed work. The postlabeling score increased from 1.0 to 2.1. The adduct levels by immunoassay increased from 0.39 to 3.08 adducts $/ 10^{7}$ nucleotides. Smoking had no effect on the level of adducts in the white blood cells, as determined by postlabeling or immunoassay, and hence there was no need to consider it.

The adduct levels of the white blood cells were analyzed by job title with the use of the postlabeling assay in one laboratory; in the early set of the samples adduct scores were given (figure 1). The level of adducts de-

Table 1. Adduct levels in individuals at work and after a fourweek vacation.

\begin{tabular}{|c|c|c|c|c|c|c|}
\hline \multirow[t]{2}{*}{ Group } & \multicolumn{3}{|c|}{$\begin{array}{l}\text { Adduct score } \\
\text { (postlabeling) }\end{array}$} & \multicolumn{3}{|c|}{$\begin{array}{c}\text { Adduct level/107 } \\
\text { nucleotides } \\
\text { (immunoassay) }\end{array}$} \\
\hline & $N$ & Mean & SE. & $\mathrm{N}$ & Mean & SE \\
\hline At work ${ }^{b}$ & 8 & 2.1 & $0.4^{\star}$ & 9 & 3.08 & $0.69^{* \star *}$ \\
\hline $\begin{array}{l}\text { After } \\
\text { vacation }\end{array}$ & 7 & 1.0 & 0.2 & 9 & 0.39 & 0.16 \\
\hline
\end{tabular}

a Score: $0<0.5,1=0.5-1.0,2=1.1-2.0,3=>2.0$ adducts $/ 10^{7}$ nucleotides.

b The workers were employed for three months after vacation.

${ }^{*} \mathrm{P}<0.05,{ }^{*}{ }^{*} \mathrm{P}<0.01$ according to the one-sided Student's ttest. 


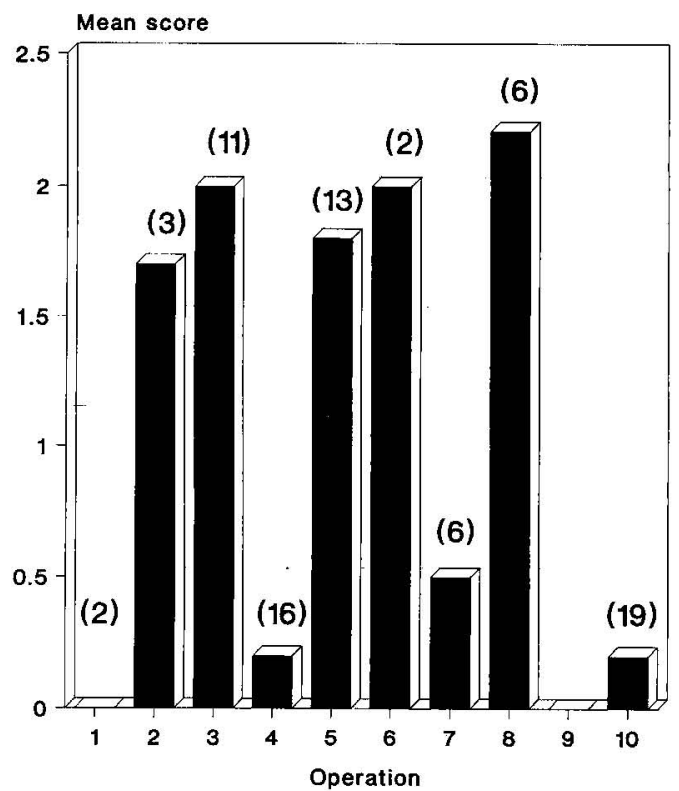

1: pattern making, 2: sand preparation, 3: moulding, 4: melting 5: casting, 6: shake-out, 7: fettling, 8 : transport, 9: other, 10; control

Figure 1. Scores of deoxyribonucleic acid adducts in white blood cells of occupational groups of foundry workers as determined by postlabeling. (Score: $0=<0.5,1=0.5-1.0,2=$ $1.1-2.0,3=>2$ adducts $/ 10^{7}$ nucleotides; number of individuals indicated at the top of the columns in parentheses) pended on the job of the worker. The results for the pattern makers and melters did not differ from those of the referents; the fettlers' adduct scores exceeded those of the referents by about 2.5 -fold. High adduct scores were measured for the workers in sand preparation, molding, casting, shake-out, and transport.

A later series of samples, entirely different from the samples in figure 1 , was assayed by three laboratories using the postlabeling technique independently. The means of the results from each laboratory are shown in figure 2. This set of workers differed from the set presented in figure 1 in two respects. The casters' adduct levels were relatively lower, and the fettlers' adduct levels higher. In other respects the results agreed. The adduct levels of the molders, melters, fettlers, and the other workers differed significantly from those of the referents.

Benzo[a]pyrene-DNA antibodies (figure 3) were used with a set of foundry worker samples that only partially overlapped with those presented in figure 1 , but which were entirely different from those in figure 2 . Again, the adduct levels of the pattern makers and melters equaled those of the referents. The workers in sand preparation had very high levels of adducts, as did transport workers and fettlers. In addition, the casters and the other workers differed significantly from the referents.

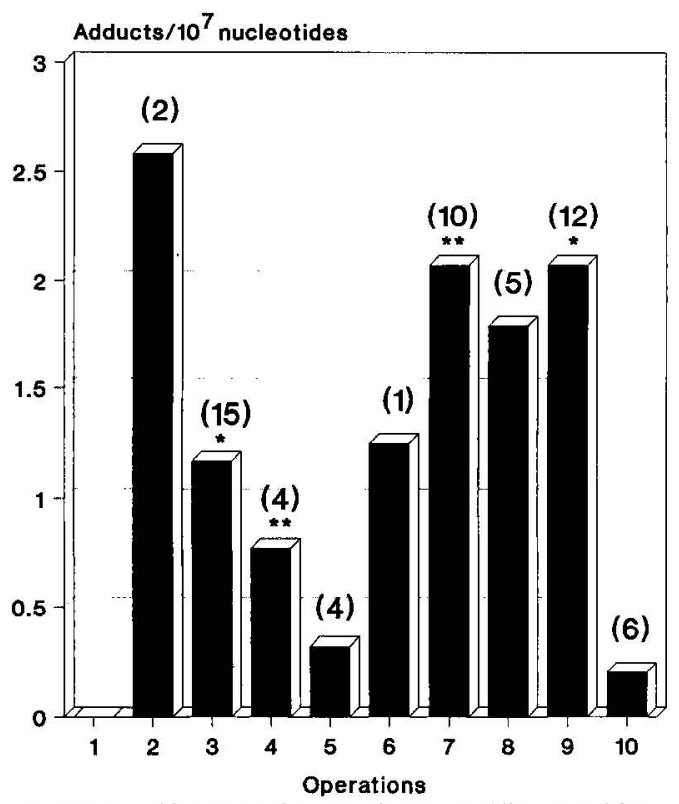

1: pattern making, 2: sand preparation, 3: moulding, 4: melting 6: casting, 6: shake-out, 7: fettling, 8: transport, 9: other, 10: control

Figure 2. Deoxyribonucleic acid adducts in white blood cells of occupational groups of foundry workers as determined by postlabeling. The results are means of determinations from three laboratories [ ${ }^{*} P<0.05,{ }^{*} P<0.01$, in comparison with the results of the referents (controls)]. (Number of individuals indicated at the top of the columns in parentheses)

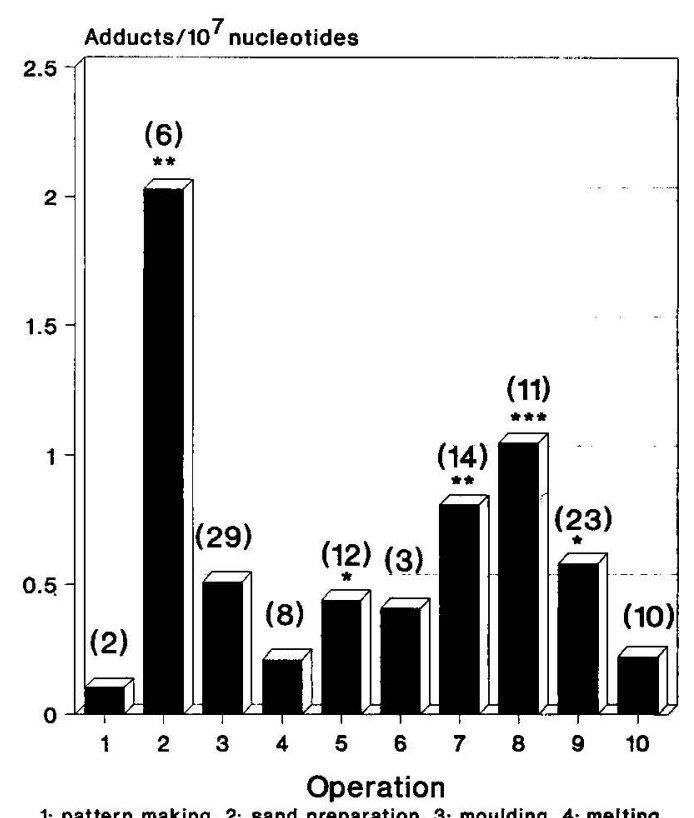

1: pattern making, 2; sand preparation, 3: moulding, 4: melting 5: casting, 6: shake-out, 7: fettling, 8: transport, 9: other, 10: control

Figure 3. Deoxyribonucleic acid adducts in white blood cells of occupational groups of foundry workers as determined by immunoassay $\left[{ }^{*} P<0.05, * * P<0.01, * * * P<0.001\right.$, in comparison with the results of the referents (controls)]. (Number of individuals indicated at the top of the columns in parentheses) 


\section{Discussion}

Iron founding is comprised of the basic operations of pattern making, molding, core making, melting, casting, shake-out, and fettling (28). However many variations exist, and modern technologies have particularly affected molding and the binding materials used. PAH are formed during the thermal decomposition of the organic ingredients of the mold material, and the levels of PAH formed are dependent on the types of molds used (29). Schimberg et al $(28,30)$ measured the concentrations of benzo[a]pyrene in air samples from two foundries using coal-tar pitch and from four foundries using coal powder sand additives. The benzo[a]pyrene levels were more than one order of magnitude higher in the foundries using coal-tar pitch binders. The foundry of our study was included in the investigations of Schimberg et al. Both coal-tar pitch binders and furan resins are used in the foundry in question.

Since PAH is predominantly formed in the casting process and released into the foundry air at the time of the casting and the shaking-out of the molds, the levels of PAH measured differed extensively by workplace (table 2). The pattern-making and melting processes usually involve a low level of exposure to PAH. Fettling is usually carried out in closed spaces, and then the exposures may be low. By contrast processes around molding, casting, and shake-out involve high levels of exposure. Transport in that area also associates with at least intermediate levels of exposure. Because PAH are absorbed to the mold sand, any reuse of sand may also entail exposure to PAH (28-30).

According to a working group of the International Agency for Research on Cancer iron founding causes lung cancer in humans $(29,31)$. One of the studies contributing to this conclusion was carried out in Finland and included a large proportion of Finnish foundry workers (32-34). This study associated the lung cancer risk to air levels of PAH. Among the various occupational groups floor molders and casters had significant excesses of lung cancer.

The present study had three individual parts. Two were carried out by postlabeling, and one by the immunoassay technique. The two different assays covered the same individuals only to the extent that has been previously reported (22); a significant correlation between the assays was noted, however. Nevertheless no proof exists that the methods measure the same types of adducts. Moreover, the quantitation does not take into account those types of adducts that react poorly in the immunoassay or label poorly in the postlabeling.

The molders had high levels of aromatic DNA adducts in all the three studies carried out. The casters had high levels in two studies. Other groups in which high levels of adducts were systematically found included the jobs of sand preparation, shake-out, and
Table 2. Concentrations of benzo[a]pyrene in air samples of iron foundries ${ }^{a}$ by workplace (coal-tar pitch method).

\begin{tabular}{lc}
\hline Operation & $\begin{array}{c}\text { Mean } \\
\text { benzo[a]pyrene } \\
\text { concentration } \\
\left(\mu \mathrm{g} / \mathrm{m}^{3}\right)\end{array}$ \\
\hline Melting & 0.2 \\
Molding & 2.2 \\
Casting & 2.1 \\
Shake-out & 12.6 \\
Fettling & 0.5 \\
Transport and others & 1.4 \\
\hline
\end{tabular}

a From two foundries given in references $28-30$.

transport. According to hygienic measurements they also entail high exposure to PAH. Although the present data tend to show high levels of DNA adducts for workers thought to be exposed to high levels of PAH, the lack of concurrent hygienic measurements, preferably by personal monitors, weakens the inferences. Furthermore, it was not known what mold material was used in each particular week of sampling, and this lack of information makes estimation of individual exposure less clear. Studies involving the personal monitoring of exposure and a determination of adduct levels are being planned.

\section{Acknowledgments}

The work was supported by the Finnish Work Environment Fund, grants CA 39174, CA 2111, CA 43263 and 5 RDI CA-39194 from the National Cancer Institute, grants $51 \mathrm{G}-13$ and $41387 \mathrm{P}$ from the American Cancer Society, and a grant from the Markey Charitable Trust.

\section{References}

1. Weinstein IB. The origins of human cancer: molecular mechanism of carcinogenesis and their implications for cancer prevention and treatment. Cancer Res 1988;48: 4135-43.

2. Bartsch H, Hemminki K, O'Neill IK, ed. Methods for detecting DNA damaging agents in humans: applications in cancer epidemiology and prevention. Lyon: International Agency for Research on Cancer, 1988. (IARC scientific publication; no 89.)

3. Farmer PH, Neumann HG, Henschler D. Estimation of exposure of man to substances reacting covalently with macromolecules. Arch Toxicol 1987;60:251—0.

4. Garner RC. Assessment of carcinogen exposure in man. Carcinogenesis 1985;6:1071-8.

5. Perera F, Weinstein IB. Molecular epidemiology and carcinogen-DNA adduct detection: new approaches to studies of human cancer causation. J Chronic Dis 1982;3:581-600.

6. Perera FP. Molecular cancer epidemiology: a new tool in cancer prevention. J Natl Cancer Inst 1987;78:88798.

7. Gupta RC, Reddy MV, Randerath K. ${ }^{32} \mathrm{P}$-postlabeling analysis of non-radioactive aromatic carcinogen-DNAadducts. Carcinogenesis 1982;3:1081-92.

8. Randerath K, Reddy MW, Gupta RC. ${ }^{32}$ P-postlabeling test for DNA damage. Proc Natl Acad Sci USA 1981; 
78:6126-9.

9. Reddy MV, Gupta RC, Randerath E, Randerath K. ${ }^{32} \mathrm{P}$-postlabeling test for covalent DNA binding of chemicals in vivo: application to a variety of aromatic carcinogens and methylating agents. Carcinogenesis 1984;5:231-43.

10. Reddy MV, Randerath K. Nuclease P1-mediated enhancement of sensitivity of ${ }^{32} \mathrm{P}$-postlabeling test for structurally diverse DNA adducts. Carcinogenesis 1986; 7:1543-51.

11. Fichtinger-Schepman AMJ, van Oosterom AT, Lohman PHM, Berends F. cis-Diamminedichloroplatinum (II)induced DNA adducts in peripheral leukocytes from seven cancer patients: quantitative immunochemical detection of the adduct induction and removal after a single dose of cis-diamminedichloroplatinum (II). Cancer Res 1987;47:3000-4.

12. Perera FP, Poirier MC, Yuspa SH, et al. A pilot project in molecular cancer epidemiology: determination of benzo(a)pyrene-DNA adducts in animal and human tissues by immunoassays. Carcinogenesis 1982;3:1405-10.

13. Poirier MC, Reed E, Zwelling LA. Ozols RF, Litterst CL, Yuspa SH. Polyclonal antibodies to quantitate cisdiamminedichloroplatinum (II) - DNA adducts in cancer patients and animal models. Environ Health Perspect 1985;62:89-94.

14. Poirier MC, Santella R, Weinstein IB, Grunberger D, Yuspa SH. Quantitation of benzo(a)pyrene-deoxyguanosine adducts by radioimmunoassay. Cancer Res 1980;40:412-6.

15. Harris CC, Vähäkangas K, Newman MJ, et al. Detection of benzo(a)pyrene diol epoxide-DNA adducts in peripheral blood lymphocytes and antibodies to the adducts in serum from coke oven workers. Proc Natl Acad Sci USA $1985 ; 82: 6672-6$.

16. Vähäkangas K, Haugen A, Harris CC. An applied synchronous spectrophotometric assay to study benzo(a)pyrene-dialepoxide-DNA adducts. Carcinogenesis 1985; 6:1109-16.

17. Weston A, Rowe ML, Manchester DK, Farmer PB, Mann DL, Harris CC. Fluorescence and mass spectral evidence for the formation of benzo(a)pyrene anti-diol epoxide -DNA and -hemoglobin adducts in humans. Carcinogenesis 1989;10:251-7.

18. Everson RB, Randerath E, Santella RM, Cefalo RC, Avitts TA, Randerath K. Detection of smoking related covalent DNA adducts in human placenta. Science 1986; 231:54-7.

19. Perera FP, Santella RM, Brenner D, et al. DNA adducts, protein adducts and sister chromatid exchange in cigarette smokers and nonsmokers. J Natl Cancer Inst 1987; 79:449-56.

20. Randerath E, Miller RH, Mittal D, Avitts TA, Dunsford HA, Randerath K. Covalent DNA damage in tissues of cigarette smokers as determined by ${ }^{32} \mathrm{P}$-postlabeling assay. J Natl Cancer Inst 1989;81:341-7.

21. Haugen A, Becher G, Bemestad C, et al. Determination of polycyclic aromatic hydrocarbons in the urine, benzo(a)pyrene diol-epoxide-DNA adducts in lymphocyte DNA and antibodies to the adducts in sera from coke oven workers exposed to measured amounts of polycyclic aromatic hydrocarbons in the work atmosphere. Cancer Res 1986;46:4178-83.

22. Hemminki K, Perera FP, Phillips DH, Randerath K, Reddy MV, Santella RM. Aromatic DNA adducts in white blood cells of foundry workers. In: Bartsch $\mathbf{H}$, Hemminki K, O'Neille IK, ed. Methods for detecting DNA damaging agents in humans: applications in cancer epidemiology and prevention. Lyon: International Agency for Research on Cancer, 1988:190-5. (IARC scientific publication; no 89.)

23. Manchester DK, Weston A, Choi JS, et al. Detection of benzo(a)pyrene diol epoxide-DNA adducts in human placenta. Proc Natl Acad Sci USA 1988;85:9243-7.

24. Perera FP, Hemminki K, Young TL, Brenner D, Kelly G, Santella RM. Detection of polycyclic aromatic hydrocarbon-DNA adducts in white blood cells of foundry workers. Cancer Res 1988;48:2288-91.

25. Phillips DH, Hemminki K, Alhonen A, Hewer A, Grover PL. Monitoring occupational exposure to carcinogens: detection by ${ }^{32} \mathrm{P}$-postlabeling of aromatic DNA adducts in white blood cells from iron foundry workers. Mutat Res 1988;204:531-41.

26. Savela K, Hemminki K, Hewer A, Phillips DH, Putman $\mathrm{KL}$, Randerath K. Interlaboratory comparison of the ${ }^{32} \mathrm{P}$-postlabeling assay for aromatic DNA adducts in white blood cells of iron foundry workers. Mutat Res $1989 ; 224: 485-92$

27. Shamsuddin AKM, Sinopoli NT, Hemminki K, Boesch RR, Harris CC. Detection of benzo(a)pyrene: DNA adducts in human white blood cells. Cancer Res 1985;45: $66-8$.

28. Schimberg RW, Pfäffli P, Tossavainen A. Profilanalyse von polycyclischen aromatischen Kohlenwasserstoffen in Eisengiessereien. Staub 1978;38:273-6.

29. International Agency for Research on Cancer. Polynuclear aromatic compounds: part 3. industrial exposure in aluminum production, coal gasification, coke production and iron and steel founding. Lyon: International Agency for Research on Cancer, 1984. (Monographs on the evaluation of the carcinogenic risk of chemicals to humans; vol 34.)

30. Schimberg RW, Pfäffli P, Tossavainen A. Polycyclic aromatic hydrocarbons in foundries. J Toxicol Environ Health 1980;6:1187-94.

31. International Agency for Research on Cancer. Overall evaluations of carcinogenicity: an updating of IARC monographs 1-42. Lyon: International Agency for Research on Cancer, 1987. (IARC monographs on the evaluation of carcinogenic risks to humans; suppl 7.)

32. Koskela R-S, Hernberg S, Kärävä R, Järvinen E, Nurminen M. A mortality study of foundry workers. Scand J Work Environ Health 1976;2(suppl 1):73-89.

33. Tola S, Koskela RS, Hernberg S, Järvinen E. Lung cancer mortality among iron foundry workers. J Occup Med 1979;21:753-60.

34. Tola S. Epidemiology of lung cancer in foundries. $\mathbf{J}$ Toxicol Environ Health 1980;6:275-80.

Received for publication: 27 October 1989 